\title{
Proteína-C-Reativa e Doença Cardiovascular. As Bases da Evidência Científica
}

\author{
Wellington Bruno Santos, Evandro Tinoco Mesquita, Rosa Maria R. Vieira, Beni Olej, \\ Mário Coutinho, Alvaro Avezum
}

Niterói, RJ - Florianópolis, SC - São Paulo, SP

Nos últimos anos testemunhamos o acúmulo de evidências sobre o papel da inflamação na fisiopatogenia da aterosclerose e ocorrência de eventos aterotrombóticos, como determinantes dos quadros de síndromes coronarianas agudas (SCAs) e acidentes vasculares cerebrais isquêmicos ${ }^{1-8}$. Com o peso destas evidências, a aterosclerose passou, gradualmente, de um modelo de doença crônicodegenerativa e, exclusivamente de pacientes de idade avançada, para um modelo de doença inflamatória crônica subclínica, presente já na infância ${ }^{9}$ e que avança, de forma generalizada, mas com alguns sítios de predileção, durante toda a vida, até que, por comprometimento extenso dos vasos ou por complicação aterotrombótica, determina a apresentação clínica de uma doença cardiovascular, cerebrovascular, renovascular ou arterial periférica ${ }^{3}$.

Marcadores inflamatórios, como a proteína-C-reativa titulada (PCR-t $)^{8-18}$, fibrinogênio ${ }^{19,20}$, proteína sérica amilóide A $^{10,13,14}$, citocinas ${ }^{13,14,16}$ e o comportamento de células do sangue periférico envolvidas na inflamação, como leucócitos $^{21-25}$, linfócitos ${ }^{22,23}$ e monócitos ${ }^{25}$ vêm sendo intensamente estudados nos portadores de angina estável ${ }^{10,17,18,26}$, angina instável ${ }^{10,14,15,17,18,27}$, infarto agudo do miocárdio ${ }^{14,15,28-33}$, doenças isquêmicas cerebrovasculares ${ }^{34,35}$, doenças arteriais periféricas ${ }^{35}$ e nos indivíduos aparentemente saudáveis ${ }^{35-37}$ com a ajuda do avanço tecnológico obtido na determinação da concentração sérica destes parâmetros.

Pela facilidade de determinação da concentração sérica e melhor correlação clínico-epidemiológica até então, a PCR-té um marcador inflamatório de especial interesse ${ }^{37,38}$. Estudos experimentais ${ }^{39-43}$, imuno-histopatológicos ${ }^{44,45}$,retrospectivos ${ }^{28}$, transversais ${ }^{46}$, casos-controles ${ }^{34,47,48} \mathrm{e}$ coortes prospectivos ${ }^{10,18,20,30-33,35-37,49-54}$ utilizando a PCR como marcador inflamatório, e estudos de redução da proteí-

Universidade Federal Fluminense, Universidade Federal de Santa Catarina, Instituto Dante Pazzanese de Cardiologia.

Correspondência: Wellington Bruno Santos - Rua Coronel Moreira César, 229/911

- 24230-052 - Niterói, RJ - E-mail: wbruno@cardiol.br

Recebido para publicação em $9 / 5 / 01$

Aceito em 6/5/02
na-C-reativa titulada (PCR-t) através de medidas farmacológicas ${ }^{26,34,35}$ e não-farmacológicas ${ }^{26}$ vêm sendo apresentados à comunidade médico-científica. Estudos que são de especial interesse dada a possibilidade de iluminar novos caminhos para a prevenção e tratamento de doenças de alta prevalência, morbidade e mortalidade em todo o mundo.

\section{Leucócitos, citocinas, hepatócitos, PCR, sistema complemento, fator tecidual, moléculas de adesão}

Os leucócitos podem ser ativados por lesão tecidual (necrose ou isquemia), pela presença de LDL-colesterol oxidada, ou pela presença de agente infeccioso na parede vascular ou em qualquer sítio orgânico (doença periodontal, infecções virais) ${ }^{1-3,56,57}$. Uma vez ativados, iniciam a produção de diferentes citocinas iterleucinas, fator de necrose tumoral alfa, interferon gama ${ }^{1,2}$. Especialmente, a interleucina-6 (Il-6) estimula os hepatócitos a produzir RNAm para produção de proteínas de fase aguda (fibrinogênio, PCR, amilóide sérico A ${ }^{57}$. Entre as proteínas de fase aguda, a PCR destaca-se por apresentar meia-vida plasmática curta (aproximadamente 19h), e a sua concentração plasmática exclusivamente relacionada à síntese nesse período ${ }^{37,58}$. Através de técnicas de imunohistoquímica, a PCR tem sido também observada nos tecidos inflamados ${ }^{59}$, no miocárdio infartado ${ }^{60} \mathrm{e}$ nas placas de aterosclerose ${ }^{38,44}$. Seu papel biológico não está totalmente esclarecido ${ }^{38}$, mas sabe-se que ela é capaz de ativar o sistema complemento ${ }^{44,45}$, intimamente relacionado aos estágios iniciais do processo de formação da placa aterosclerótica ${ }^{39,45}$ e, também, relacionado ao estímulo da síntese de fator tecidual pelos monócitos (efeito procoagulante) ${ }^{61,62}$. As citocinas estimulam ainda a expressão de moléculas de adesão, contribuindo para a interação entre monócitos e células endoteliais ${ }^{63-65}$. Por outro lado, a PCR também apresenta ação antiinflamatória ao inibir a adesão de neutrófilos e células endoteliais através da inibição da expressão de L-selectina e ao inibir a produção de superóxido, pelos neutrófilos e estimular a síntese de antagonista do receptor de Il-1 pelos monócitos ${ }^{66}$. Outro dado relevante, derivado de estudos em ratos Knockout para antagonistas de receptores de interleu- 
cina-1(Il-1)-outra citocina proinflamatória que estimula maior produção de Il-6 e, conseqüentemente, de PCR - é que esses ratos desenvolvem inflamação arterial letal nas bifurcações e flexuras de suas artérias que, nos seres humanos, correspondem às regiões de alta turbulência e formação de placas ateroscleróticas ${ }^{67}$.

\section{Métodos de dosagem da PCR}

As primeiras determinações de PCR eram realizadas por soroaglutinação em partículas de látex em lâmina, sendo o resultado expresso semiquantitativamente em cruzes $(+/$ $++++)$, a partir de uma interpretação subjetiva. Posteriormente, foi possível a determinação quantitativa da concentração sérica da PCR através de imunoturbidimetria e nefelometria, expressando-se os resultados em $\mathrm{mg} / \mathrm{dL}^{68}$. Entretanto, esses métodos têm sensibilidade reduzida para detecção de baixos níveis de inflamação: a determinação da concentração sérica mínima é em torno de $0,31 \mathrm{mg} / \mathrm{dL}$ pelos dois métodos em nosso laboratório do Hospital Universitário Antônio Pedro. A sensibilidade imunonefelometria é insuficiente em $30 \%$ dos casos, segundo Haverkate e cols. ${ }^{25}$, chegando a $40 \%$ em nosso serviço (dados não publicados). Concentrações séricas, a partir de $0,072 \mathrm{mg} / \mathrm{dL}$, já conferem risco aumentado de eventos cardiovasculares ao indivíduo. Atualmente, a imunonefelometria hipersensível (também denominada de alta sensibilidade ou ultra-sensível) é o método de escolha para determinação da concentração sérica da proteína-C-reativa titulada ${ }^{7,21,22,37}$. Diversos estudos prospectivos ${ }^{34,36,37,47,48,53}$ e casos-controles ${ }^{34,47,48}$ têm sido publicados com a utilização desse método.

A interpretação do resultado requer cuidadosa correlação com a história clínica e exame físico do paciente, uma vez que processos inflamatórios ou estados gripais elevam os níveis basais de PCR-t. Mais de uma determinação pode ser necessária para uma correta avaliação do risco relativo de um paciente.

\section{A PCR e as doenças cardiovasculares}

Estudos in vitro, in vivo e imuno-histoquímicos Embora não saibamos o real papel biológico da PCR, estudos imuno-histoquímicos demonstraram sua presença nos tecidos inflamados ${ }^{59}$, nos vasos ateroscleróticos ${ }^{38,44}$ e no miocárdio infartado ${ }^{60}$. Tem sido demonstrado que a PCR aumenta a expressão do fator tecidual (efeito procoagulante) ${ }^{61,62}$, de moléculas de adesão ${ }^{63-65}$, liga-se à lipoproteínas plasmáticas e ativa o sistema complemento in vitro ${ }^{39} \mathrm{e}$ in vivo ${ }^{40}$, presente na maioria das células esponjosas (foam cells) das placas ateroscleróticas.

Recentemente, Stefanadis e cols. demonstraram direta correlação entre aumento da temperatura da placa e níveis mais altos de PCR-t e proteína sérica amilóide em pacientes com síndromes coronarianas agudas ${ }^{69}$.

Estudos genéticos - A produção hepática de PCR é fundamentalmente modulada pela Il-6, embora a Il-1 e o fator de necrose tumoral alfa (TNF-alfa) também participem desta modulação ${ }^{57}$. Ratos Knockout para gene de Il-6 apresentam resposta inflamatória inadequada, enquanto os animais Knockout para Il-1 e TNF-alfa mantêm a produção das prote- ínas de fase aguda ${ }^{70,71}$. Portanto, a PCR é um indicador direto dos níveis de Il-6 in vivo ${ }^{72,73}$. Recentemente, foi identificado polimorfismo na região promotora do gene de Il-6, de forma que os homozigóticos para o alelo $\mathrm{C}$, com menor resposta inflamatória, parecem estar protegidos contra infarto agudo do miocárdio antes dos 40 anos de idade, enquanto os homozigóticos para o alelo G estão sob maior risco de exacerbação da resposta inflamatória aos insultos ambientais ${ }^{57}$. Este fato é de especial relevância devido a observação de que alguns pacientes apresentam resposta inflamatória exacerbada à angioplastia (maior produção de PCR, proteína sérica amilóide A, Il-6) ${ }^{13}$. Também nos faz especular quanto a possibilidade do fator genético configurar diferente intensidade de resposta inflamatória à presença de patógenos nos vasos (ex.: Chlamydia pneumoniae), nas infecções sistêmicas (ex.: viremias) ou nos sítios à distância (ex.: doença periodontal), como determinante na progressão da doença aterosclerótica e ocorrência de fenômenos aterotrombótico.

PCR e disfunção endotelial - Recentemente, foram publicados relatos de associação entre elevação da PCR-t e marcadores indiretos de ativação endotelial (fator de von Willebrand, molécula de adesão celular vascular-1 [VCAM1]) ${ }^{74,75}$. Cleland e cols. demonstraram que níveis mais altos de PCR-t apresentam relação inversa com a síntese de óxido nítrico endotelial basal através de medida direta invasiva em pequeno grupo de indivíduos ${ }^{76}$. Embora esses dados sugiram relação entre inflamação, disfunção endotelial e risco cardiovascular, necessitam de confirmação através de estudos maiores.

PCR e a extensão da doença aterosclerótica - $\mathrm{Na}$ ausência de necrose miocárdica, níveis mais elevados de PCR-t correlacionam-se com maior extensão da doença aterosclerótica, mesmo após correção para outros fatores de risco ${ }^{35,77}$. Indivíduos, aparentemente saudáveis, com níveis mais altos(mesmo em níveis considerados normaisaltos) apresentam maior risco de desenvolvimento de doença arterial periférica ${ }^{35}$.

PCR e gravidade da doença cardiovascular - Nos pacientes com infarto agudo do miocárdio, níveis mais elevados de PCR-t correlacionam-se com maior extensão da área de necrose miocárdica ${ }^{30-33}$. A PCR-t correlaciona-se também com maior mortalidade nos primeiros 6 meses, em seguida ao infarto agudo do miocárdio tratado com trombolítico, mesmo após correção para a extensão da área de necrose ${ }^{52}$. A PCR-t $\geq 0,2 \mathrm{mg} / \mathrm{dL}$ correlacionou-se com maior risco de ruptura miocárdica em estudo retrospectivo de 37 pacientes com infarto agudo do miocárdio ${ }^{28}$, e confirmada, posteriormente, em estudo prospectivo de 1997 com 220 pacientes, que sofreram o primeiro infarto agudo do miocárdio ${ }^{35}$. Nos portadores de angina estável ${ }^{18}$ e angina instável ${ }^{18,20,44,50}$, a PCR-t correlaciona-se com maior risco de eventos coronarianos (infarto agudo do miocárdio, necessidade de angioplastia ou cirurgia de revascularização miocárdica ou morte súbita).

Estudos transversais - Em 1996, Mendall e cols. estudaram 388 homens entre 50 e 69 anos de idade e demonstraram que a concentração sérica de PCR correlaciona-se com os outros fatores de risco cardiovasculares(fatores lipídicos, hemostáticos e infecciosos, obesidade, tabagismo, idade) e que sua elevação está fortemente associada à doença coronariana ${ }^{46}$. 
Estudos de caso e controle aninhados e coortes prospectivas -Em 1996, Kuller e cols. demonstraram, através de estudo caso-controle aninhado com 256 indivíduos com idade entre 35 e 57 anos (MRFIT), acompanhados prospectivamente durante 10 a 17 anos, que os níveis basais de PCR-t correlacionavam-se com aumento estatisticamente significativo da mortalidade por doença coronariana em homens fumantes de alto risco (risco relativo $=4,3 \mathrm{e}$ intervalo de confiança de $95 \%=1,7-10,8)$. Nesse estudo, não foi demonstrada a associação com infarto do miocárdio não-fatal, comparando-se o $1^{\circ}$ e o $4^{\circ}$ quartil dos valores da PCR-t (risco relativo $=1,0$ e intervalo de confiança $95 \%=$ 0,4-2,5) ${ }^{47}$. Em 1997, Ridker e cols. compararam 543 homens portadores de doença cardiovascular e 543 controles do Physicians 'Health Study (PHS), após seguimento de 8 anos, e demonstraram que os níveis basais de PCR-t no $4^{\circ}$ quartil triplicavam o risco de ocorrência de infarto do miocárdio $(\mathrm{RR}=2,9, \mathrm{IC} 95 \%=1,8-4,6)$ e duplicavam o risco de acidente vascular cerebral isquêmico $(\mathrm{RR}=1,9$, IC 95\% $=$ 1,8-4,6) ${ }^{34}$.Em 1998, os mesmos autores, analisando a mesma amostragem, observaram um aumento de 4 vezes no risco de desenvolver doença arterial periférica $(\mathrm{RR}=4,1, \mathrm{IC} 95 \%=$ 1,2-6,0) ${ }^{35}$. Ainda em 1997, Tracy e cols. compararam 146 homens e mulheres idosos(idade $\geq 65$ anos), inicialmente sem doença coronariana, que apresentaram infarto agudo do miocárdio não-fatal ou morte atribuída a doença coronariana, com um grupo controle de 146 pessoas com as mesmas características e sem evento coronariano num seguimento de 2,4 anos: níveis mais elevados de PCR-t associaram-se a risco aumentado de eventos coronarianos, principalmente nas mulheres idosas com doença subclínica (índice tornozelo-braço > 0,9, aumento da espessura médiointimal, doença carotídea assintomática, eletrocardiograma anormal, alteração da função sistólica global ou segmentar do ventrículo esquerdo) ${ }^{48}$. Em 1998, Ridker e cols. também demonstraram que níveis mais altos de PCR-t (e também da proteína amilóide sérica), dosados cerca de 8,9 meses após o primeiro infarto agudo do miocárdio, associavam-se a risco aumentado de eventos coronarianos fatais e nãofatais, comparando-se o mais baixo e o mais alto quintil dos níveis de PCR- $\mathrm{t}^{55}$. Todos esses estudos foram corrigidos para outros fatores de risco estabelecidos.

Estudos prospectivos de pacientes com infarto agudo do miocárdio ${ }^{30-33,44,49}$, angina instável ${ }^{37,44,50}$ dor torácica atípica ${ }^{50}$ e angina de peito estáve ${ }^{44,50,51}$, utilizando métodos de diferentes sensibilidades, com amostras pequenas (a maior foi de 108 portadores de infarto agudo do miocárdio, por Pietilä ${ }^{33}$ ), com seguimento curto ( 4 a 14 dias, havendo um com seguimento de 6 meses, por Liuzzo e cols. ${ }^{17}$ ), e não corrigidos para outros fatores de risco, foram publicados entre 1982 e 1995, sugerindo a importância da inflamaçãoe da determinação sérica da PCR-t para a estratificação de risco das SCAs ${ }^{30-33,38,44,49,50}$. Anzai ${ }^{29}$, em 1997, também publicou um estudo prospectivo com um ano de seguimento de 220 pacientes com primeiro infarto agudo do miocárdio, não corrigido para outros fatores de risco em que demonstrou que níveis elevados de PCR-t após infarto agudo do miocárdio correlacionavam-se com maior risco de ruptura de parede, formação de aneurisma ventricular e maior mortalidade em um ano.

O European Concerted Action on Thrombosis and
Disabilities (ECAT) acompanhou, por 2 anos, 743 pacientes com angina de peito estável, 1030 com quadro de angina instável e 326 pacientes com quadro de dor torácica aguda, com correção para outros fatores de risco. Foi demonstrado que a PCR-t correlacionou-se com risco aumentado de eventos coronarianos, independentemente da extensão da doença coronariana ${ }^{18}$. Embora esse estudo possa receber críticas sobre a possibilidade da isquemia poder induzir uma reação de fase aguda, em vez de ser propriamente um efeito da SCA ${ }^{62}$, Liuzzo e cols. demonstraram em 1996 que a resposta das proteínas de fase aguda não é induzida pela isquemia em pacientes com angina variante ${ }^{17}$. Corroborando esse dado, estudos prospectivos de pessoas aparentemente saudáveis (homens e mulheres de meia-idade e idosos) demonstraram que níveis mais altos de PCR-t associam-se realmente com risco aumentado de eventos coronarianos, independentemente de outros fatores de risco estabelecidos ${ }^{34,36,37,48,53}$.

PCR como fator de risco em indivíduos assintomáticos - Baseados nos estudos MRFIT (Multiple Risk Factor Intervention Trial) ${ }^{47}$, que randomizou homens de alto risco, PHS (Physicians'Health Study) ${ }^{53}$, randomizando homens de baixo risco, CHS/RHPP (Cardiovascular Health Study/Rural Health Promotion Project) ${ }^{48}$, randomizando homens e mulheres saudáveis com idade $\geq 65$ anos, WHS (Women's Health Study) ${ }^{36}$, randomizando mulheres de meia-idade, aparentemente saudáveis, e no estudo MONICA (Monitoring Trends and Determinants in Cardiovascular Disease), randomizando homens e mulheres, aparentemente saudáveis, entre 45 e 64 anos de idade, a determinação sérica da PCR-t por nefelometria hipersensível em homens e mulheres de meia-idade e idosos apresenta relevante informação quanto ao risco relativo de eventos cardiovasculares nesses grupos populacionais. Ridker e cols. demonstraram ainda que a concentração sérica colesterol HDL tem seu valor preditivo para infarto agudo do miocárdio aumentado quando associado a níveis mais elevados de PCR-t ${ }^{53,78}$. Danesh e cols. realizaram recente metanálise dos estudos prospectivos relevantes e identificaram um odds ratio de 2,13 (IC 95\% = - 3,28) após ajuste para idade, cidade, tabagismo, fatores de risco vasculares e indicadores do estado socioeconômico ${ }^{79}$. Em estudo coorte, Margaglione e cols. observaram que indivíduos sem evidência de aterosclerose, porém descendentes de pessoas que sofreram infarto agudo do miocárdio, apresentavam níveis mais elevados de PCR-t (>0,33mg/L), quando comparados a indivíduos sem parentes de $1^{\circ}$ grau, que sofreram infarto agudo do miocárdio ${ }^{80}$.

Estratégias de redução da PCR - Em 1997, Ridker e cols. publicaram o primeiro estudo demonstrando que o efeito da redução de eventos cardiovasculares, resultante da terapia com ácido acetilsalicílico associava-se a redução concomitante dos níveis séricos de PCR-t ${ }^{34}$. Em 1999, Ikonomidis e cols. demonstraram redução de citocinas inflamatórias e da PCR-t com uso de ácido acetilsalicílico com uma casuística de 60 portadores de angina estável e 24 controles $^{26}$. Posteriormente, a pravastatina, utilizada na prevenção primária e secundária da doença coronariana, também teve seu efeito benéfico associado à redução dos níveis séricos de PCR-t ${ }^{55,81}$.Em 2001, Ridkere cols. demonstraram que era possível fazer prevenção primária de eventos coronarianos agu- 
dos, nos pacientes com níveis de colesterol relativamente baixos, e com PCR elevada através do uso de lovastatina ${ }^{82}$ Estudo pequeno de Sattar e cols. demonstrou que a TRH em 33 mulheres diabéticas tipo 2 e pós-menopáusicas reduziu os níveis de PCR-t, sugerindo possível mecanismo antiinflamatório para a redução de eventos cardiovasculares desse tratamento ${ }^{83}$. Smith e cols. demonstraram que o exercício físico de longa duração é capaz de reduzir significativamente as citocinas inflamatórias e os níveis de PCR-t em estudo pequeno (43 voluntários), sugerindo participação de um efeito antiinflamatório para justificar os benefícios do exercício para prevenção de doenças cardiovasculares ${ }^{16}$.

\section{Conclusão e perspectivas futuras}

A aterosclerose e os fenômenos aterotrombóticos são processos fundamentalmente decorrentes da inflamação. Especificamente, a participação da PCR diretamente na ate- rogênese e no desencadeamento dos fenômenos aterotrombóticos tem sido sugerida por estudos in vitro, in vivo e imuno-histoquímicos, embora não tenhamos evidências robustas e definitivas para caracterização de seu real papel nesses processos. A elevação do nível de PCR é um preditor independente de evolução adversa nos pacientes com angina instável ou infarto sem onda $\mathrm{Q}^{84,85}$. Tem sido claramente demonstrado que a PCR constitui-se em um importante marcador de inflamação vascular subclínica crônica (inflamação de baixo grau) e de risco cardiovascular, apresentando valor preditivo positivo independente e adicional às dosagens de lípides plasmáticos e presença de outros fatores de risco bem estabelecidos, através de estudos prospectivos ${ }^{86-90}$. A PCR, determinada por método hipersensível, poderá futuramente deixar de ser um fator de risco condicional pela American Heart Association/American College of Ccardiology ${ }^{90}$ para ser considerada um fator de risco independente maior.

\section{Referências}

1. Ross R. The pathogenesis of atherosclerosis: a perspective for the 1990s. Nature 1993; 362: 801-09.

2. Libby P. Molecular bases of the acute coronary syndromes. Circulation 1995; 91 2844-50.

3. Berliner AB, Navab M, Fogelman AM, et al. Atherosclerosis: basic mechanismsoxidation, inflammation, and genetics. Circulation 1995; 91: 2488-96.

4. Ross R. Atherosclerosis- an inflammatory disease. N Engl J Med 1999; 340 $115-26$

5. Entman ML, Ballantyne CM. Inflammation in acute coronary syndromes Circulation 1993; 88: 800-03.

6. Falk E, Shah PK, Fuster V. Coronary plaque disruption. Circulation 1995; 92 : $657-71$

7. BiasucciLM, Colizzi C, Rizzello V,Vitrella G,CreaF,Liuzzo G. Role of inflammation in the pahogenesis of unstable coronary artery disease. Scand J Clin Lab Invest Suppl 1999; 230: 12-22.

8. Ridker PM. C-reactive protein and the risks of future myocardial infarction and thrombotic stroke. Eur Heart J 1998; 19: 1-3.

9. Verri J, Fuster V. Mecanismos das síndromes isquêmicas agudas e da progressão da aterosclerose coronária. Arq Bras Cardiol 1997; 68: 461-7.

10. Liuzzo G, Biasucci LM, Gallimore JR, et al. The prognostic value of C-reactive protein and serum amyloid A in severe unstable angina. N Engl J Med 1994; 331: 417-24.

11. Anderson JL, Carlquist JF, Muhlestein JB, Horne BD, Elmer SP. Evaluation of C reactive protein, an inflammatory marker, and infectious serology as risk factor for coronary artery disease and myocardial infarction. J Am Coll Cardiol 1998; 32 $35-41$.

12. Biasucci LM, Liuzzo G, Grillo RL, et al. Elevated levels of C-reactive protein at discharge in patients with unstable angina predict recurrent instability. Circulation 1999; 99: 855-60.

13. Liuzzo G, Buffon A, Biasucci LM, et al. Enhanced inflammatory response to coronary angioplasty in patients with severe unstable angina. Circulation 1998; 98: 2370- 6 .

14. Liuzzo G, Biasucci LM, Gallimore JR, et al. Enhanced inflammatory response in patients wih preinfarction unstable angina. J Am Coll Cardiol 1999; 34: 1696-1703.

15. Morrow DA, Rifai N, Antman EM, et al. C-reactive protein is a potent predictor of mortality independently and in combination with troponin $\mathrm{T}$ in acute coronary syndrommes: a TIMI 11 A Substudy. J Am Coll Cardiol 1998; 31: 1460-5.

16. Smith JK, Dykes R, Douglas JE, Krishnaswamy G, Berk S. Long-term exercise and atherogenic activity of blood mononuclear cells in persons at risk of developing ischemic heart disease. JAMA 1999; 281: 1722-7.

17. Liuzzo G, Biasucci LM, Rebuzzi AG, et al. Plasma protein acute-phase response in unstable angina is not induced by ischemic injury. Circulation 1996; 94: 2373-80.

18. Haverkate F, Thompson SG, Pyke SDM, et al. Production of C-reactive protein and risk of coronary events in stable and unstable angina. Lancet 1997; 349: 462-6.

19. Becker RC, Cannon CP, Bovill EG, et al. Prognostic value of plasma fibrinogen concentration in patients with unstable angina and non-Q-wave myocardial infarction (TIMI IIIB Trial). Am J Cardiol 1996; 78: 142-7.

20. Toss H, Lindahl B, Siegbahn A, Wallentin L (for The Frisc Study Group).
Prognostic influence of increased fibrinogen and C-reactive protein levels in unstable coronary artery disease. Circulation 1997; 96; 4204-10.

21. Ernst E, Hammerschmidt DA, Bagge U, et al. Leukocytes and the risk of ischemic disease. JAMA 1987; 257: 2318-24.

22. Thomson SP, Gibbon RJ, Smars PA, et al. Incremental value of the leukocyte differential and the rapid creatine-kinase-MB isoenzyme for the early diagnosis of myocardial infarction. Ann Intern Med 1995; 122: 335-41.

23. Kannel WB, Anderson K, Wilson PWF. White blood cell count and cardiovascular disease: insights from the Framingham Study. JAMA 1992; 267: 1253-6.

24. Ribeiro AD. Proteína-C-reativa e contagem total e diferencial de leucócitos como fatores prognósticos na angina instável. Monografia de Conclusão de Curso apresentada ao Departamento de Cínica Médica do Curso de Graduação em Medicina do Centro de Ciências da Saúde da Universidade Federal de Santa Catarina. Florianópolis, 1997

25. Ikata J, Wakatsuki T, Oishi Y, Oki T, Ito S. Leukocyte counts and concentration of soluble adhesion molecules as predictors of coronary atherosclerosis. Coron Artery Dis 2000; $11: 445-9$

26. Ikonomidis I, Andreotti F, Economou E, et al. Increased proinflammatory Cytokines in patients with chronic stable angina and their reduction by aspirin. Circulation 1999; 100: 793-8.

27. Benamer H, Steg PG, Benessiano J, et al. Comparison of the prognostic value of Creactive protein and Troponin I in patients with unstable angina pectoris. Am J Cardiol 1998; 82: 845-50

28. Ueda S, Ikeda U, Yamamoto K, et al. C-reactive protein as a predictor of cardiac rupture after myocardial infarction. Am Heart J 1996; 131: 857-60.

29. Anzai T, Yoshikawa T, Shiraki H, et al. C-reactive protein as a predictor of infarct expansion and cardiac rupture after a first $\mathrm{Q}$ wave acute myocardial infarction. Circulation 1997; 96: 778-84

30. de Beer FC, Hind CRK, Fox, et al. Measurement of C-reactive protein concentration in myocardial ischaemia and infarction. Br Heart J 1982; 47: 239-43.

31. Pietilä K, Harmoinen A, Pöyhönen L, et al. Intravenous streptokinase treatment and serum C-reactive protein in patients with acute myocardial infarction. B Heart J 1987; 58: 225-9.

32. Pietilä K, Harmoinen A, Teppo AM. Acute phase reaction, infarct size, and inhospital morbidity in myocardial infarction patients treated with streptokinase or recombinant tissue type plasminogen activator. Ann Intern Med 1991; 23: 529-35.

33. Pietilä KO, Harmoinen AP, Hermens WP, et al. Serum C-reactive protein and infarct size in myocardial infarct patients with a closed versus na open infarctrelated coronary artery after thrombolytic therapy. Eur Heart J 1993; 14: 915-19.

34. Ridker PM, Cushman M, Stampfer MJ, Tracy RP, Henneckens CH. Inflammation, aspirin, and the risk of cardiovascular disease in apparently healthy men. N Engl J Med 1997; 336: 973-9.

35. Ridker PM, Cushman M, Stampfer MJ, et al. Plasma concentration of C-reactive protein and risk of developing peripheral vascular disease. Circulation 1998 97: 425-8

36. Ridker PM, Buring JE, Shih J, Matias M, Hennekens CH. Prospective study of Creactive protein and the risk of future cardiovascular events among apparently healthy women. Circulation 1998; 98: 731-3. 
37. Koenig W, Sund M, Fröhlich M, et al. C-reactive protein, a sensitive marker of inflammation, predicts future risk of coronary heart disease in initially healthy middle-aged men- results from the MONICA (Monitoring Trends and Determinants in Cardiovascular Disease) Augsburg Cohort Study, 1984 to 1992. Circulation 1999; 99: 237-42.

38. Lagrand WK, Visser CA, Hermens WT, et al. C-reactive protein as a cardiovascular risk factor- more than an epiphenomenon? Circulation 1999; 100: 96-102.

39. Volonakis JE. Complement activation by C-reactive protein complexes. Ann N Y Acad Sci 1982; 389: 235-49.

40. Wolbink GJ, Brower MC, Buysmann S, ten Berge IJM, Hack CE. CRP-mediated activation of complement in vivo. Assesment by measuring circulating complement-C-reactive protein complexes. J Immunol 1996; 157: 473-9.

41. Zouki C, Beauchamp M, Baron C, Filep JG. Prevention of in vitro neutrophil adhesion to endothelial cells through shedding of L-selectin by C-reactive protein and peptides derived from C-reactive protein. J Clin Invest 1997; 100: 522-9.

42. Heuertz RM, Piquette CA, Webster RO. Rabbits with elevated serum C-reactive protein exhibit diminshed neutrophil infiltration and vascular permeability in C5a-induced alveolitis. Am J Pathol 1993; 142: 319-28.

43. Sinisalo J, Paronen J, Mattila KJ, et al. Relation of inflamation to vascular function in patients with coronary heart disease. Atherosclerosis 2000; 149: 403-11.

44. Lagrand WK, Niessen JWM, Wolbink GJ, et al. C-reactive protein colocalizes with complement in human hearts during acute myocardial infarction. Circulation 1997; 95: 97-103.

45. Torzerwski J, Torzewski M, Bowyer DE, et al. C-reactive protein frequently colocalizes with the terminal complement complex in the intima of early atherosclerotic lesions of human coronary arteries. Arterioscler Thromb Vasc Biol 1998; 18: 1386-92.

46. Mendall MA, Patel P, Ballam L, Strachan D, Northfield TC. C-reactive protein and its relation to cardiovascular risk factor: a population based cross sectional study. Br Med J 1996; 312: 1061-5.

47. Kuller LH, Tracy RP, Shaten J, Meilahn EN. Relation of C-reactive protein and coronary heart disease in the MRFIT nested case-control study. Am J Epidemiol 1996; 144: 537-47.

48. Tracy RP, Lemaitre RN, Psaty BM, et al. Relationship of C-reactive protein to risk of cardiovascular disease in the elderly. Arterioscler Thromb Vasc Biol 1997; 17: 1121-7.

49. Casl MT, Surina B, Glojnaric-Spastic I, et al. Serum amyloid A protein in patients with acute myocardial infarction. Ann Clin Biochem 1995; 32: 196-200.

50. Berk BC, Weintraub WS, Alexander RW. Elevation of C-reactive protein in "active" coronary artery disease. Am J Cardiol 1990; 65: 168-72.

51. Thompson SG, Kienast J, Pyke SDM, Haverkate F, van de Loo JCW. Hemostatic factor and the risk of myocardial infarction or sudden death in patients with angina pectoris. N Engl J Med 1995; 332: 635-42.

52. Pietilä KO, Harmoinen AP, Jokiniitty J, Pasternack AI. Serum C-reactive protein concentration in acute myocardial infarction and its relationship to mortality during 24 months of follow-up in patients under thrombolytic treatment. Eur Heart J 1996; 17: 1345-9.

53. Ridker PM, Glynn RJ, Henneckens CH. C-reactive protein adds to the predictive value of total and HDL cholesterol in determing risk of first myocardial infarction. Circulation 1998; 97: 2007-11.

54. Cook DG, Mendall MA, Whincup PH, et al. C-reactive protein concentration in children: relationship to adiposity and other cardiovascular risk factors. Atherosclerosis 2000; 149: 139-50.

55. Ridker PM, Rifai N, Pfeffer MA, et al, for the Cholesterol and Recurrent Events (CARE) Investigators. Inflammation, pravastatin, and the risk of coronary events after myocardial infarction in patients with average cholesterol levels. Circulation 1998; 98: 839-44.

56. Oparil S, Oberman A. Nontradional cardiovascular risk factors. Am J Med Sci 1999; 317: 193-207.

57. Yudkin JS, Kumari M, Humphries SE, Mohamed-Ali V. Inflammation, obesity, stress and coronary heart disease: is interleukin-6 the link? Atherosclerosis 2000; 148: 209-14.

58. Vigushin DM, Pepys MB, Hawkins PN. Metabolic and scintigraphic studies of radioiodinated human $\mathrm{C}$-reactive protein in health and disease. J Clin Invest 1993; 91: 1353-7.

59. Hatanaka K, Li XA, Masuda K, Yutani C, Yamamoto A. Immunohistochemical localization of C-reactive protein-binding sites in human atherosclerotic aortic lesions by a modified streptavidin-biotin-staining method. Pathol Int 1995; 45: 635-41.

60. Kushner I, Rakita I, Kaplan MH. Studies of acute phase protein, Il: localization $\mathrm{Cx}$-protein in heart in induced myocardial infarction in rabbits. J Clin Invest 1963; 42: 286-92.

61. Cermak J, Key NS, Bach RR, et al. C-reactive protein induces human peripheral blood monocytes to synthesize tissue factor. Blood 1993; 82: 513-20.

62. Ridker PM, Haughie P. Prospective studies of C-reactive protein as a risk factor for cardiovascular disease. J Investig Med 1998; 46: 391-5.

63. Meisel SR, Shapiro H, Radney J, et al. Increased expression of neutrophil and monocyte adhesion molecules LFA-1 and Mac-1 and their ligand ICAM-1 and VLA-4 throughout the acute phase of myocardial infarction- possible implications for leukocyte aggregation and microvascular plugging. J Am Coll Cardiol 1998; 31: 120-5.
64. Mazzone A, De Servi S, Ricevuti G, et al. Increased expression of neutrophil and monocyte adhesion molecules in unstable coronary artery disease. Circulation 1993; 88: 358-63.

65. Hasdai D, Scheinowitz M, Leibovitz E, et al. Increased serum concentrations of interleukin $1-B$ in patients with coronary artery disease. Heart 1996; 76: 24-8.

66. Gabay C, Kushner I. Mechanism of disease: acute-phase proteins and other systemic responses to inflammation. N Engl J Med 1999; 340.

67. Dinarello CA. The role of the interleukin-1-receptor antagonist in blocking inflammation mediated by interleukin-1. N Engl J Med 2000; 343: 732-4.

68. Lima JCC, Correia LCL, Silva AM, Lima DL. Usando proteína C reativa de alta sensibilidade(PCR-AS) como preditor de doença cardiovascular. Newslab 2000; 41: 164-6.

69. Stefanadis C, Diamantopoulos L, Dernellis J, et al. Heat production of atherosclerotic plaques and inflammation assessed by acute phase proteins in acute coronary syndromes. J Moll Cell Cardiol 2000; 32: 43-52.

70. Fantuzzi G, Zheng H, FaggioniR, et al. Effect of endotoxin in Il- $1 B$ deficient mice J Immunol 1996; 157: 291-6.

71. Marino MW, Dunn A, Grail D, et al. Characterization of tumor necrosis factor alfa deficient mice. Proc Natl Acad Sci USA 1997; 94: 8093-8.

72. Bataille R, Klein B. C-reactive protein levels as a direct indicator of Interleukin6 levels in humans in vivo. Arhritis Rheum 1992; 35: 982-3.

73. Harris TB, Ferrucci L, Tracy RP, et al. Association of interleukin-6 and C-reactive protein levels with mortality in the elderly. Am J Med 1999; 106: 506-12.

74. Schalkwijk CG, Poland DC, van Dijk, et al. Plasma concentrations of C-reactive protein is increased in type -1 diabetic patients without without clinical macroangiopathy and correlates with markers of endothelial dysfunction: evidence for chronic inflammation. Diabetologia 1999; 42: 351-7.

75. Yudkin JS, Stehower SCA, Emeis JJ, Coppack SW. C-reactive protein in healthy subjects: associations with obesity, insulin resistance, and endothelial dysfunction- a potential role for cytokines originating from adipose tissue? Arterioscler Thromb Vasc Biol 1999; 19: 972-8

76. Cleland SJ, Sattar N, Petrie JR, et al. Endothelial Dysfunction as a possible lynk between C-reactive protein levels and cardiovascular disease. Clinical Science 2000; 98: 531-5

77. Heinrich J, Schulte H, Schönfeld R, Köhler E, Assmann G. Association of variables of coagulation, fibrinolysis and acute phase with atherosclerosis in coronary and peripheral arteries and those arteries supplying the brain. Thromb Haemost 1995; 73: 374-8

78. Ridker PM, Henneckens CH, Buring JE, Rifai N. C-reactive protein and other markers of inflammation in the prediction of cardiovascular disease in women. $\mathrm{N}$ Engl J Med 2000; 342: 836-43.

79. Danesh J, Whincup P, Walker M, et al. Low grade inflammation and coronary heart disease: prospective study and updated meta-analyses. Br Med J 2000; 321(7255): 199-204

80. Margaglione M, Cappucci G, Colaizzo D, et al. C-reactive protein in offspring is associated with the occurrence of myocarial infarction in first-degree relatives. Arterioscler Thromb Vasc Biol 2000; 20: 198.

81. Albert MA, Danielson E, Rifai N, Ridker PM. PRINCE Investigators. Effects of statin therapy on C-reactive protein levels: the pravastatin inflammation/CRP evaluation (PRINCE); a randomized trial and cohort study. JAMA 2001; 286: 64-70.

82. Ridker PM, Rifai N, Clearfield M, et al. Measurement of C-reactive protein for the targeting of statin therapy in the primary prevention of acute coronary events. $\mathrm{N}$ Engl J Med 2001; 36: 1959-65.

83. Sattar N, Perera M, Small M, Lumsden M. Hormone replacement therapy and sensitive C-reactive protein concentrations in women with type- 2 diabetes. Lancet 1999; 354: 487-8.

84. Lindahl B, Toss H, Siegbahn A, et al. Markers of myocardial damage and inflammation in relation to long-term mortality in unstable coronary artery disease. N Engl J Med 2000; 343: 1139-47.

85. Mueller C, Buettner HJ, Hodgson JM, et al. Inflammation and long-term mortality after non-ST elevation acute coronary syndrome treated with a very early invasive strategy in 1042 consecutive patients. Circulation 2002; 105: 1412-15.

86. Zebrack JS, Muhlestein JB, Horne BD, Anderson JL. The Intermountain Heart Collaboration Study Group. C-reactive protein and angiographic coronary artery disease: independent and additive predictors of risk in subjects with angina. J Am Coll Cardiol 2002; 39: 632-7.

87. Zebrack JS, Anderson JL, Maycock CA, et al. Usefulness of high-sensitivity Creactive protein in predicting long-term risk of death or acute myocardial infarction in patients with unstable or stable angina pectoris or acute myocardial infarction. Am J Cardiol 2002; 89: 145-9.

88. Horne BD, Muhlestein JB, Crlquist JF, et al. Statin therapy, lipid levels, Creactive protein and the survival oof patients with angiographically severe coronary artery disease. J Am Coll Cardiol 2000; 36: 1774-80.

89. Libby P, Ridker PM, Maseri A. Inflammation and Atherosclerosis. Circulation 2002; 105: 1135-43.

90. Grundy SM, Pasternak R, Greenland P, Smith Jr S, Fuster V. Assessment of cardiovascular risk by use of multiple-risk-factor assessment equations: a statement for healthcare professionals from the American Heart Association and the American College of Cardiology. Circulation 1999; 100: 1481-92. 